\title{
IMPROVING ENGLISH VOCABULARY ABILITY THROUGH WORD SEARCH GAME OF THE SEVENTH GRADE STUDENTS OF SMPN 2 ABIANSEMAL IN ACADEMIC YEAR 2009/2010
}

\author{
Ida Ayu Made Sri Widiastuti \\ English Education Department, Faculty of Education and Teacher Training, \\ University of Mahasaraswati Denpasar
}

\begin{abstract}
The present classroom action study dealt with Improving the Students English Vocabulary Through Word Search Game of the Seventh Grade Students of SMPN 2 Abiansemal in Academic Year 2009/2010. The present classroom action study was basically triggered by the fact that the subjects under study still faced problem in vocabulary mastery. The subjects' vocabulary problem should be instantaneously solved. Words Search Game were expected to be an effective way in improving and developing the vocabulary mastery of the Sevent Grade Students of SMPN 2 Abiansemal in Academic Year 2009/2010. The present classroom action study made use of pre-test and post-test research design with descriptive and quantitative analysis. It consists of two cycles and in each cycle there are four successive sessions. The present classroom action study was started with administering initial refelction (IR) to the subjects under study which was intended to establish the real preexisting vocabulary mastery of the subjects under study. The comparation of mean score of each session within each cycle shows a significant increase. This grand mean figure convincingly increased much higher than the mean figure of the initial reflection or pretest scores. This grand mean figure convincing reveals that there were significant Improvement of the Students' English Vocabulary of the Seventh Grade Students of SMPN 2 Abiansemal. The questionnaires which were actually intended to measure the changing learning behavior of the subjects under study in learning vocabulary taught through Words Search Game were administered by the end of the cycle I. The results of the comparative percentage figures obtained for the present class study proved that the subjects' learning behavior changed positively, that was, their attitude and motivation heightened significantly.
\end{abstract}

\section{Key Words: vocabulary, Ability, Word Search Game}

\section{INTRODUCTION}

Language plays a central role in human life. It provides a vehicle for communication, a tool for thinking, a means of creativity and a source of pleasure. An understanding of language and the ability to use it effectively gives students access to knowledge, enables them to play an active part in the society and contributes to their personal growth. Language is the most significant possession of human being. It is means for human beings to communicate their ideas and to convey information. 
English is one of the most important communications. This fact can be seen in Indonesia. English is learnt widely either for general or specific purposes in formal as well as in informal educational institution. In Indonesia English is the first foreign language which is taught as compulsory subject in the school from the elementary school until university. It is stated in curriculum based competence of SMP that learning English is concerned with it`s four basic skills namely, listening, speaking, reading and writing. Moreover, there are some aspects of language that should be taught to develop these four skills such as: grammar, vocabulary, pronunciation and spelling. Mastering each of these skills is absolutely important as others, they are closely related to one another.

\section{Vocabulary is an aspect of language that has been taught by the teacher in} teaching English as a second language or foreign language. Teaching vocabulary is important because it is as a basic to communication, if learners don not recognize the meaning of keywords they will be unable to participate the conversation, even if they know the morphology and syntax, so the students firstly should master a large number of vocabulary, without having this they can not express themselves clearly and effectively.

Students must be able to master in active and also in passive vocabulary. Active vocabulary is the words they should be able to use in speaking and writing. Passive vocabulary is the words they should be able to recognize and understand when they are listened to someone or when they are reading (Heaton, 1989:9).Some research findings also disclose that students who have acquired more vocabulary items, they will be more likely to have better ability to articulate and communicate the massage. Further more, vocabulary has four aspects namely: pronunciation, spelling, meaning, and usage. It is mean that in learning vocabulary the students must be able to pronounce the words correctly, to spell the words, to know the meaning of words and to use the words.

Based on the importance of vocabulary in language learning, the researcher found a fact that the seventh grade students of SMPN 2 Abiansemal have problems in English vocabulary. When students can not speak English, it does not mean that they have no idea but they have not get enough words to express their ideas but sometime 
they do not know how to use the words and put them in a sentences. This phenomenon may be caused by the teacher's technique which is used inappropriate in teaching vocabulary. English teachers put the emphasis on structure or grammar, than vocabulary. As the result, the students' vocabulary is very poor. It is the reason why teaching English for students should focus on an effort to build up the students vocabulary, by the use of game it is believed to be able to increase the student's motivation, interest, and enjoyment in learning, so that it results better learning.

Considering the phenomena mentioned above, the researcher is interested in attempting to overcome the students' problem by means of using a technique called word search game. Word search game is one type of activities that can be applied to give the students practice in learning vocabulary. Moreover, it might be possible to improve the students' vocabulary through word search game.

In relation to this, the present study is aimed at improving the students in the seventh grade students of SMPN 2 Abiansemal, Badung in English vocabulary through word search game.

\section{Research Problem}

In accordance to the background of the study above, in this research the researcher is expected to find out an appropriate technique that can be used to help the students to get the interesting material of vocabulary and interesting game. The problems investigated in the present study can formulated as follows, to what extent can the student's English vocabulary of the seventh grade students of SMPN 2 Abiansemal, Badung in the academic years 2009/2010 be improved through words search game?.

\section{The Purpose of the Research}

Based on the statement of the problem above, this study is conducted in order to improve the ability of the seventh grade students of SMPN 2 Abiansemal in English vocabulary through words search game.

\section{Limitation of the Study}

Related to previous objectives mentioned, this study is restricted to improving the ability of class seventh grade students of SMPN 2 Abiansemal in academic year 
2009/2010 in English vocabulary. The words used in this study are English words that are suggested by the currently used teaching syllabus especially for junior high school students.

This study is expected to be uses as a valuable input or feedback in increasing the effectiveness of techniques at improving the student's ability in English vocabulary.

\section{The Underlying Theories Used in this Research}

Vocabulary learning is central to language acquisition, whether the language is first, second, or foreign. Although vocabulary has not always been recognize as a priority in language teaching, interest in its role in second language(L2) learning has grown rapidly in recent years and specialist now emphasize the need for a systematic and principle approach to vocabulary by both the teacher and the learner ( Murcia, 2001: 285)

Vocabulary is the main tool for language learners, especially the students in the process of learning, mastering and using the language they learn language as an important means of communication. According to Hornby (1978: 1331), Vocabulary is the total number of words, which make up language. He believes that a number of meaningful words or a phrase builds a language. Some one who is skillful in the four English skills (speaking, listening, writing and reading) must have rich and extended mastery of vocabulary items, words and phrases, which constitute of the bulk of the language.

Vocabulary is one of the major problems encounter by teaching of English as a foreign language (TEFL). It is considered to be the most important aspect in foreign language learning. Many students fail to communicate effectively because they do not have sufficient vocabulary mastery.

Penny - Ur (1998:60 ) assert that vocabulary can divined, roughly, as the words we teach in the foreign language. However, a new item of vocabulary maybe more than single word, which made up two or three words but expresses a single idea. There are also multi words - idioms where the meaning of the phrase cannot be 
deduced from an analysis of the component words. A useful convention is to cover all such cases by talking about vocabulary items, rather than words.

Words are very important in language learning - words are the tools we use to think, to express ideas and feeling, and to learn about the world, because words are very foundation of an educational priority. Hill (1999) in reniti (2009:8) explains that most learners with 'good vocabularies' have problem with fluency because their' collocational competence' is very limited and that especially from intermediate level, we should aim at increasing their collocation competence with the vocabulary they have already got. For advance learners he also suggests building an what already know, using better strategies and increasing the number of items they meet outside the classroom.

Mastering vocabulary is also very important in order that learners are able to understand the meaning. e.g. the text in English. In the Budiawan in Kasmawati (2008:10) say that second language or foreign language, readers often cited 'lack of vocabulary 'as one of the outside to text comprehension. It means that the readers 'comprehension upon the text will be influenced by they familiarities with vocabulary in it. By mastering a large number of vocabularies, the learners will be able to understand the massage of the text well.

Now days it is widely accepted that vocabulary Teaching should be part of the Syllabus, and taught in well-planned and regular basis. Therefore, it could be said that vocabulary plays an important role in target language, as the object of language teaching is to cultivate student's skill namely reading, speaking, listening and writing. Vocabulary in needed to interact and to express the ideas in the target language. By mastering an adequate vocabulary, the learners will be able to communicate easily and fluently with other people and understand other's ideas even to speak and write fluently.

Teaching vocabulary is very challenging and interesting tasks for the teacher. Several techniques and tools can be used in teaching vocabulary. It is very difficult to determine with one is the best way: however, the teacher should be able to select the 
most appropriate way and tool to ensure the improvement of the students 'vocabulary mastery"

Some of the most common techniques used in teaching vocabulary item: (1) Teaching vocabulary through song: (2) Teaching vocabulary through pictures, and (3) Teaching vocabulary through games. Teaching vocabulary by using games considered a good technique because it gives much practice and fun in learning.

Jeremy Harmer (2007:238) states that there are many games which are appropriate for use with collection of vocabulary items which designed to engage students with a list of vocabulary items.

Achievement test that measure the extent of this learning perhaps do have a part to play institutional testing. For those who believe the systematic teaching of vocabulary is desirable, vocabulary achievement tests are appreciated for their backwash effect. The usefulness of a general diagnostic test of vocabulary is not readily apparent. As far as placement test are concerned, we would not normally require, or expect, a particular set of lexical items to be prerequisite for a particular language class. All we would be looking for is some general indication of the adequacy of the students vocabulary. The learning of specific lexical items in class will rarely depend on previous knowledge of other, specified items. O ne alternative is to use a published test of vocabulary. The other is to construct one's own vocabulary proficiency test.

Assessment can be administered by carrying out a series of tests. Test may be constructed primarily as devices to reinforce learning and to motivate the students or primarily as a mean of assessing the students performance in the language ( Heaton, 1998:5). In relation to this study, the researcher will focus on testing the student's performance in vocabulary achievement when words search game as a tool. The researcher anticipates that the test will give objective feedback for both students and the researcher.

\section{Subjects of the Study}

The subjects of this study were the seventh grade students of SMPN 2 Abiansemal, Badung in academic year 2009/2010. The researcher simply selected 
class VII G which consisted of 50 students. This group of the students were selected as the subjects of the study because the students' vocabulary mastery in the class was still unsatisfactory

\section{RESEARCH DESIGN}

This research was classroom-based action research that was aimed at improving the seventh grade students in English vocabulary through word search game at SMPN 2 Abiansemal. This classroom action research started by giving pretest which was Initial Reflection (IR) or pre-test in order to have a glimp of preexisting vocabulary mastery of the subjects, while Reflection (R) or post-test which was administered at the end of each cycle, was intended to reveal the expected increase in the students' vocabulary after applying the word search game in the process of teaching the students..

In this classroom action study, the teaching and learning processes were divided into two cycles in which each cycle consisted of four sessions. This research consisted of four activities: planning, action, observation, and reflection. However, before the researcher implemented the cycle, pre-test was given to the subjects in order to know their initial level of the students' mastery in vocabulary. It is necessary to note the pre-test was a term normally used in a classroom action study. The mean scores of the pre-test was compared to the mean scores of the post test administered at the end of each cycle for the sake of establishing the degree of the increasing vocabulary mastery of the subjects.

\section{FINDINGS AND DISCUSSION}

The data analysis leads to the establishment of the finding of the present class room action study which investigates the effectiveness of the Word Search Game in improving vocabulary mastery of the seventh grade students of SMPN 2 Ambiansemal Denpasar. The mean of IR (initial replection) or pre-test scores (X0) obtained by the subjects under study in vocabulary pointed out that the mean figure was 4.23. This mean figure clearly showed that the pre-existing vocabulary of the students was very low. The result of the data analysis of the reflection scores in cycle I showed the increasing mean figures $4.83,5.53,6.13$ and 6.58 of for S1 (cycle), S2, 
S3 and S4 respectively. The mean figures obtained by the students of each session in cycle I, is clearly much higher than the mean figure of IR score. The grand mean figure of the reflection or post-test scores obtained by subjects under study was much higher than the mean figure of the IR scores. The resulted grand mean figure for cycle I is 5.77. This grand mean figure was convincingly discovered much higher than the mean figure of the IR scores. This grand mean figure convincingly revealed that the teaching vocabulary to the seventh grade students of SMPN 2 Ambiansemal Denpasar through Word Search Game significantly improved.

The results of the data analysis of the reflection or post-test scored obtained by the students in cycle II turned out to show the progressing mean figures of 7.15, 7.58, 8.00 and 8.63 respectively. Compared with the mean figure of IR scores, the mean figure obtained by the students for each session was convincingly much higher then the IR mean figure. The grand mean figure of the reflection or post-test score obtained by the subjects under study in cycle II was 7.84 . There was a clearly different mean figure of 2.07 between cycle I and cycle II. This significant difference mean figure suggests that the teaching of vocabulary in cycle II (S5, S6, S7, and S8) through Word Search Game could be remarked to be more effective than cycle I. This was due to the fact that the cycle II was a revised version of cycle I, in that the teaching scenarios in cycle II were accordingly revised by taking into account the weaknesses found out in cycle I.

The results of the analysis of the questionnaires scores shows the comparative percentages of $51.99 \%, 27.66 \%, 17.04 \%$, and 3.31 for items A, B,C, and D respectively. The questionnaires which were actually intended to measure the changing learning behavior of the subjects under study in learning vocabulary taught through Word Search Game were administered by the end of the cycle I. The results of the comparative percentage figures obtained for the present class room study proved that the subjects' learning behavior changed positively, that was, their attitude and motivation heightened significantly.

The findings of the present classroom action study are believed to have rather limited validity as well as reliability. This is due to the fact that during the undertaking of this study, there are some compounding variables which were simply 
not adequetly controlled. Therefore these research findings are applicable only to the subjects under study, and the English teacher of other classes should carefully adopt and make use of these findings.

\section{CONCLUSIONS AND SUGGESTIONS}

The discussions through out the present action study are finally concluded in this chapter. Some practical suggestions in reference to the significance of the established research findings are also recommended.

\section{Conclusions}

The present class action study deals with improving the vocabulary of the seventh grade students of SMPN 2 Ambiansemal Denpasar through Word Search Game. The selection of the seventh grade students of SMPN 2 Ambiansemal Denpasar was preceded by conducting a preliminary study. Based on the study it was found that the seventh grade students of SMPN 2 Ambiansemal Denpasar students faced a big problem in learning vocabulary.

The improvement of the vocabulary ability of the students through Word Search Game using class action study which made use of a pre-test, post-test design was divided into two cycles, where in each cycle consisted of four successive sessions. The main data required for the present class action study were collected through administering IR and post-test in each session, some supporting data were collected by means of administering questionnaires by the end of cycle I. The administration of the IR to the students resulted the mean figure of Xo $=4.23$. This mean figure clearly showed the low ability of the students in vocabulary. The means of reflection scores in cycle I obtained by the subjects under study showed the successive mean figures of 4.83, 5.53, 6.13 and 6.58 for S1, S2, S3, and S4 respectively. The grand mean of the reflection scores in cycle I figured the mean figure of $\mathrm{XI}=5.77$, while the means of reflection scores in cycle II obtained by the subjects under study showed the successive mean figure of 7.15, 7.58, 8.00 and 8.63 for S5, S6, S7, and S8 respectively The grand mean of the reflection scores in cycle II figured the mean figure of XII $=7.84$. Compared with the obtained IR mean figure of 4.23 , it was clear that the established mean figure for each session was much higher 
than the IR mean figure. From S1 to S8 the resulted mean figures progressed and increased significantly.

The results of the analysis of the questionnaire scores lucidly showed the comparative percentage figures of $51.99 \%, 27.66 \%, 17.04 \%$, and 3.31 for the respective total responses of the items of the questionnaire showing $\mathrm{A}, \mathrm{B}, \mathrm{C}$, and D. These findings substantially proved that the attitudes and the learning motivation of the subjects under study changed and heightened positively.

It could therefore be concluded that improving the students' vocabulary mastery through Word Search Game was really an effective technique.

\section{Suggestions}

In the finding of the present action study, the researcher would like to suggest the following practical points:

The English teachers of the seventh grade students of SMPN 2 Ambiansemal Denpasar are further suggested to be more active in collecting different kind of Word Search Game from different available sources. These Word Search Game were very useful to develop the students' ability in vocabulary.

The English teachers of the seventh grade students of SMPN 2 Ambiansemal Denpasar were suggested to be more active, creative and innovative in experimenting the use of Word Search Game in teaching vocabulary.

The use of Word Search Game in improving vocabulary was proved to be very effective. In line with this, the English teachers are highly suggested to use this technique continuously and make effective use of different kind of Word Search Game.

\section{REFERENCES}

A.J.Thomson,1986. A Practical English Grammar,London: Oxford University Press,New York

Ayu Rini,2005.Excellent English Games.Jakarta:Kesaint Blanc Jakarta.

Carroll, Bredan J and Patrick J. Hall. 1985. Make Your Own Language Tests. New York: Pergamon Press. 
Chastain, Kenneth. 1998. Developing Second Language Skill. University of Virginia. Charlottrsville. Virginia

David Cross, 1991.A Practical Handbook Of Language Teaching, England.British Library Cataloguing in Publication Data.

Heaton,J.B.1975.Writing English Language Test.A Practical Guide for Teacher of English as a Foreign Language: Longman Group United.

Hornby, A.S. 1980. Oxford Advance Learner's Dictionary of Current English. Third Edition. Oxford University Press.

Jeremy Harmer.2007. The Practice of English Language Teaching, England: Person Education Limited.

Krisna Ari Susanti, Komang,2007.Improving Students Ability In Reading Comprehension Through SQ3R Technique To The Seventh Grade Students of SMP Negeri 3 Denpasar In Academic Year Of 2006/2007. Unpublished Thesis FKIP Universitas Mahasaraswati Denpasar

Marianne Celce-Murcia.2001 Teaching English as a Second or Foreign Language, United States: Printed in United States of America

Mercer, C.D. 1989. Teaching Students with Learning Problems, New York: Columbus Merril Publishing Company.

Nunu, David. 1992. Research Methods in Language Learning. Cambridge University Press

Palmer, Ardian. 1983. Games in language Teaching 2 Language Teaching the International Abstracting Journal for Language Teacher and Applied.Vol. 16 No. $15-16$

Penny Ur.1998. A Course in Language Teaching. Cambridge : Cambridge University Press

Philips,Sarah,2003.Young Learners, China Oxford University Press.

Wikipedia. 2001. Discovery School's word search Maker. Discovery School.com

William, A.A. 1970. Basic Subject for the Slow Learner. California: Methuen Educational Limited.

Young, R.M. and Savage H. 1982. Better Learning: How to Help Student of All Ages Overcome Learning Problem and Learning Disabilities. New Jersey: Prentice Hall, Inc 